\title{
Dogme 95 and the Reality of Fiction
}

\author{
By Gabriel Giralt
}

Fall 2003 Issue of KINEMA

WHATEVER HAPPENED TO REALITY: DOGME AND THE REALITY OF FICTION

"The 'supreme' task of the decadent film-makers is to fool the audience. Is that what we are so proud of? Is that what ' 100 years' have brought us? Illusions via which emotions can be communicated? ... By the individual artist's free choice of trickery? ... To Dogme 95 the movie is not an illusion!...Dogme 95 counters the film of illusion by the presentation of an indisputable set of rules known as The Vow of Chastity."

(extract from Dogme 95 manifesto)

AFTER few international successes, Dogmesecretariat, the official entity responsible for issuing Dogme certificates, a guarantee that a film has been made following rigorously Dogme's "Vow of Chastity" is closed. After eight years since the group wrote its manifesto and five years since the movement brought forth its first Dogme film, the contention that "to Dogme 95 the movie is not an illusion" remains unexplained. Dogme reaction against the illusory technological gadgetry of commercial cinema remains a paradox. Peter Schepelern from the University of Copenhagen, now the person in-charge of the Dogme archives and academic research, sees Dogme's reaction against the illusory aspects of the hi-tech cinema justified but at the same time troublesome.

"The most telling philosophical weakness in the argument [referring to Dogme's manifesto] is the fact that the most logical but paradoxical consequence of Dogme's initiative to spurn technology would involve elimination of the camera itself. In other words, if we are intent on getting rid of all the technical aids which are employed to make films, why should we spare the most dominant? The camera is the object that is most contrary to the natural order!"(1)

The paradox that Professor Schepelern addresses not only points to the unresolved dilemma between two inseparable entities, cinema and technology, but more crucially, the tension between the fictional and the factual inherent in the film image. That is, in the factual realm it is said that the camera's lens "sees" candidly what "is" in front of it. However, in the fictional realm the optical image remains an illusion and not reality. Such illusion is easily proven if we consider the chromatic (colour) and spherical (shape) distortions inherent in the lens in the formation of the optical image, and the fact that once we place a lens cup in front of the lens, the optical image ceases to exist although reality remains. Therefore, a naturalistic and realistic approach to film never captures reality and its spontaneity as it "is". This seems to be an impossibility since reality is always in constant growth and decay, always expanding or shrinking. The best that film or any electronic device can do is to freeze nature's spontaneity in terms of size, colour, shape, etc. in discrete fragments or frames to later recreate the illusion of constant motion. Of course, the film's illusion of continuous motion poses a problem. It hides from the viewer the empty gaps of life, space and time that exist in-between frames. In sum, the usage of the lens, the framing and its motion in the act of filming is a contrived exploitation of what is being filmed. The entire irony of the Dogme's claim: "a Dogme movie is not an illusion" is that Dogme 95 falsely assumes that there is a filmed "human fact" that exists that is not itself fictionally devised and contrived.

It is the thrust of this paper to suggest that cinema, either Classical Hollywood or the Dogme movement, like any Art form is entirely subjective and experiential. However, there are different in-depth levels of subjectivity. The nuances of one of these depths may claim to be more successful than another in speaking of reality. In this sense, Dogme 95 claims to be more truthful than Hollywood. This claim is acceptable yet subject to dispute. However, what is not acceptable is the Dogme manifesto's claim that a Dogme film provides a more truthful approach to reality itself. In doing so, the Dogme group ends up with an inextricable and insoluble dilemma. That is, Dogme's intended realism to counteract Hollywood's illusion, ends up reinventing a new fiction.

The Dogme Claim

The Dogme group has always viewed themselves as one of the avant-guard forces leading the evolving identity 
of the European Cinema. Their innovative approach to narrative film was made manifest in their intent to reform Europe's mainstream aesthetics from the influence of Hollywood's popularity and control of the film industry and market. To Dogme, Hollywood's "high-tech perfectionism had come to dominate the filmmaking process" transforming it into a homogeneous commercialized spectacle. ${ }^{(2)}$ Hence, Dogme's intentions, together with its manifesto, were said to guarantee the European Cinema's return to its original state of purity and authenticity. This reform was crystallized in a "Vow of Chastity" in which ten technical mandates were intended to provide the requirements guaranteed to enable the filmmaker to capture reality on its own terms without the artificial veneer of the "bourgeois" or commercial cinema. To Dogme, some of the agents responsible for fostering and perpetuating such commercialization, were the filmmakers who once revolted against popular conventions and later were absorbed by mainstream cinema.

In 1960 enough was enough! The movie was dead and called for resurrection. The goal was correct but the means were not! The new wave proved to be a ripple that washed ashore and turned to muck... The anti-bourgeois cinema itself become bourgeois, because the foundations upon which its theories were based was the bourgeois perception of art... ${ }^{(3)}$

The assimilated avant-garde cinema to which the Dogme manifesto's text alludes is the short-lived French New Wave that, with the exception of some directors such as Chabrol, Godard, Truffaut, Bresson, Resnais, and a few others, conformed to the mainstream dominant iconography. However, the "bourgeois" cinema to which Dogme objects is not the French New Wave, but the current Hollywood or any cinema practice that follows similar narrative and stylistic structure of reducing the entire production to high-tech technology, sophisticated lighting schemes and labourious cinematographic processes (filters, dolly shots, etc.). Their objection is against the complete subjugation of the narrative and stylistic system to this technical manipulation and control designed to exploit the film's illusionistic apparatus.

To Dogme 95 the movie is not illusion! Today a technological storm is raging of which the result is the elevation of cosmetics to God. By using new technology anyone at any time can wash the last grains of truth away in the deadly embrace of sensation. The illusions are everything the movie can hide behind. ${ }^{(4)}$

Dogme's effort to liberate reality from "cosmetics" and to return to cinema's spontaneity and freshness "is not about non-interference with reality which preoccupied cinema verite". ${ }^{(5)}$ Meaning, the filmmaker searches for objectivity without tampering with the world present in front of the lens. Instead Dogme has invented a new artificiality expressed by a new crude style of "grain, jump-cuts, a rawness of technique that crosses certain avant-garde practices". (6)

However, Dogme's claim that reality is captured by spontaneous acting, hand held camera, natural lighting, direct sound, jump-cut editing, no special effects, no filters, etc. does not free the group from a new invented artificiality. Its effort to free itself from the illusory clutches of Hollywood or cinema itself is a failure. The entire effort to bring about a spontaneous cinematic experience as it seeks to capture the essence of what is in front of the camera lens is a calculated controlled effort, which is entirely subjective.

Dogme's theoretical exposition of its newly invented realism involves a technological dilemma that touches upon the paradoxical tension between the fictional and the factual bipolarity inherent in cinema. That is, it is assumed that the camera's eye "sees" what "is." This is taken as a fact. However, the very use of a camera's lens is itself an artificial device (i.e., a fictional intrusion). Hence, the "natural" photographic reproduction of any action never captures what is "spontaneous" precisely because it is itself a "contrived" and "calculated" control and exploitation of what is being filmed and depicted. The "essence" of what is being filmed is always beyond the camera's lens. The camera's eye is merely a mechanism and not a living, animated organism. When the human eye "sees" a red object, it "sees" a substance because its sight is animated with the person's intelligence. When the camera's eye captures the same scenario it cannot "see" a red object. It merely visualizes a succession of "happenings" which are placed together (as frames in a filmstrip) as an "event" that ends when we place the lens cap in front of the lens.

\section{Two Worlds of Subjectivity}

Such controversial dilemmas regarding the fictional and the factual in film are not entirely new. If we were to ask Andre Bazin about the artificiality of film, he probably would have answered a categorical No to 
artificiality, since he states that the essence of the film image is essentially objective in nature. He bases his position on the assertion that the film image is formed without the intervention of any human agent. That is, a film image is a mechanical reproduction without human participation. "For the first time an image of the world is formed automatically, without the creative intervention of man". ${ }^{(7)}$ He goes even further by pointing out that even the very name of the lens, in french called "objectif", is reminiscent of such objectivity. ${ }^{(8)}$ For Bazin the photographic image is just what happens automatically when the light reflected from an object strikes the film's surface (i.e., chemical layer or emulsion).

"Photography affects like a phenomenon in nature, like a flower or snowflake whose vegetable or earthly origins are inseparable part of their beauty". ${ }^{(9)}$ Later on, in the same chapter ("The Ontology of the Photographic Image), Bazin again underscores the objective essence of photography, adding: "Only the impassive lens, stripping its object of all whose ways of seeing it, those piled-up preconceptions, that spiritual dust and grime with which my eyes have covered it, is able to present it in all its virginal purity to my attention and consequently to my love". ${ }^{(10)}$ ) Therefore, Bazin's view is that the objective quality of the photograph is what "gives the medium its privileged relationship with the real". (11)

With the very same lens, Rudolph Arnheim rejects Bazin's notion of objectivity as he goes on at length talking about how an image is creatively formed. ${ }^{(12)}$ He provides a long list of properties (depth, size of an image colour/B\&W, motion, camera angle, etc.) that the film image acquires in the process of transforming a three dimensional reality into a two dimensional plane. Arnheim's rejection of Bazin's objectivity is based on "the assertion that film is nothing but the feeble mechanical reproduction of real life."(13) For Arnheim then, the film image cannot escape from subjectivity since the angle, the distance, the type of lens and so on are decisions the filmmaker takes being entirely optional and arbitrary. Therefore, the process is more mental than factual. The film image cannot take place apart from a contextual significance which issues from the author/director's own frame-of-mind, a frame-of-mind that is entirely prejudicial.

For Arnheim what Bazin over looks is that the camera lens is itself an artificial fabrication of human ingenuity. It cannot capture reality "as is." It can only depict a person's subjective vision of reality. In other words, the camera can, with a wide-angle lens "visualize" an entirely different scene than can the very same camera with a telephoto lens. The very "decision" to employ one lens over another is a human decision which is entirely artificial and not really "spontaneous." In other words, the camera can visualize better than the natural eye can, but it cannot in its mechanical /electronic procedure actually "see" what it visualizes. Hence, it cannot understand what it visualizes. All of this is an artificial device that emphasizes the filmmaker's subjectivity. In sum, the result of Bazin and Arnheim's positions are two views of reality which are entirely subjective even though one side claims to be objective (realistic) and the other subjective (expressionistic).

Therefore, Dogme's manifesto falsely assumes "to Dogme 95 the movie is not illusion"(14) that there is a photographic "human fact" that the camera can grasp that is not itself artificially (i.e., fictionally) devised. Again, underlying this false assumption is the tension between factualism and fictionalism. David Bordwell in his book, "Narration in the Fiction Film," deals with this paradox by stating that the modern realism of the European Art Cinema is not more real than that of Classical Hollywood's representation of reality rooted in late nineteen century realism. Their difference lies in their formal approach as they look at their object of interest. ${ }^{(15)}$ Their objectivity (i.e., "reality") emerges from the filmmaker's subjectivity and the particular "preference" that the filmmaker has for an attitudinal mindset. ${ }^{(16)}$ Both sides, the European Art Cinema and Classical Hollywood, proceed from a "preferential" conscious decision to adopt that position.

Ironically enough, each "preferential" side can make the other appear to be what itself is not, since both sides are diametrically opposed to each other. For example, the subjectivity of the Expressionist film (traditionally a film descended from the European Art Cinema) can make the realism of classical Hollywood (i.e., the Realist film) appear to be "fictional" while the objectivity of the Hollywood film can make the Expressionist appear fictional. How is that so? To the Expressionistic film everything begins with what is perfectly conceivable and logically rational. What is not, is illogical and outside of the rational grasp. On the other hand, to the Realist or Classical Hollywood film everything begins with what is empirically observable and what one experiences with one's senses. Therefore, for the Expressionist "reality" is mental, (i.e. intellectual) and elusive. For the Realist "reality" is visceral. The entire complex is one of paradox in a "have/have-not" situation. That is, if one emphasizes the Expressionistic or illusory mindset, one misses out the Realistic 
mindset, and vice versa. But, paradoxically, one cannot pursue one without bringing the other into attention.

\section{Dogme's Formal Structure}

It is not in the pure act of reality's reproduction that Dogme 95 wrongly claimed to distinguish itself from main-stream cinema but at the level of subjectivity. Professor Schepelern acknowledges that it is precisely within the level of fiction, the filmmaker's "subjective preference" and not in "the pursuit of reality's unembellished truth" that Dogme 95 contends against hi-tech illusory cinema.

"... the whole point of Dogme 95 is not to emulate documentarism, since this would make it appear conventional rather than innovative. Dogme aims instead to challenge the conventions of the fiction film in order to create a dialectic relationship between fiction and the search for truth. In this respect, it is expressing the same tendencies evident as far back as neo-realism, a movement that also sought to banish the art of illusion and replace it with a truthful portrayal of reality within the bounds of fiction"(17)

Dogme's representation of "reality" challenges Hollywood's realism in terms of narrative and praxis. Technically speaking, Dogme 95 interest is to highlight what the average American film overlooks. Therefore, Dogme's narrative aligns itself with the European Art Cinema discourse rooted in authorial expressivity, narrative ambiguity and self-reflexivity. ${ }^{(18)}$ That is, if the characters in the Hollywood structure are the main motivators of change in the narrative and have well defined traits, goals, and objectives, in the Dogme structure, the character's objectives are obscure and their traits do not have a particular function in the plot. In The Idiots (1998) we don't know much about Karen until the end where we learn that she had run away from her family and husband after the death of her baby. The same goes for the rest of the characters where we learn bits and pieces of their lives but their traits do not provide a close function with the narrative development as is the case in the Classical Hollywood narrative.

Similarly, the Hollywood structure is based primarily on cause/effect relationships propelling the story action forward in a definite direction to meet specific goals. In the Dogme structure, the cause/effect relationship of the events is suppressed. Instead, the Dogme narrative is motivated by two principles: realism and authorial expression. Realism means that the narrative deals with actual contemporary life issues as it criticizes and questions social, political and ideological aspects of life. Authorial expressivity means the author plays an integral part in the formulation of meaning in the film's narrative. In The Celebration, (1998) the narrative uses the theme of child abuse and incest as a catalyst to expose the problem of fascism as well as the prevalence of racism with the recent emergence of ultra-nationalist groups in Denmark. ${ }^{(19)}$

In terms of narrative, it is important to note that although these two formal structures, Dogme and Classical Hollywood, appear strikingly different, at times it is hard to isolate one from the other, since both share common formal traits. The difference will be always a matter of degree, as their narrative formal conventions appear closer or further apart from each other.

In terms of praxis, Dogme accomplishes its objective of being the antithesis of Hollywood by producing low budget, highly creative narrative films stripped of the sanitized gloss of the mainstream production code which is entirely subjugated to the high-tech cinema spectacle. Dogme certainly defies the Hollywood expectation of how a film should look. However, in spite of its commitment to strip from the production process all kinds of mainstream stylistic conventions, the Dogme film scarcely breaks new ground. Aside from the usage of hand-held digital video cameras and total restriction of non-diegetic sound, etc, the bulk of Dogme stylistic elements are those that characterized Italian Neo-realism (i.e. Visconti's La Terra Trema (1947), Rosselini's Rome Open City (1945), De Sica Bicycle Thieves (1948)); and French New Wave (i.e. Truffaut's Shoot the Piano Player (1960), Godard's Breathless (1959), Chabrol's The Unfaithful Wife (1968)) as reform movements against the illusory and seamless commercialized films of their day.

Dogme's cinematic practice rests its foundation on Italian Neorealism's basic principles, which reject artificial sets for location shooting, use natural lighting, and focus interest on contemporary, true-to-life subjects with open-ended plots, active viewer involvement, implied social criticism, etc. ${ }^{(20)}$ In the same manner, Dogme's shared relationship with the French New Wave rests on its subversive character a film stripped of any sense of perfectionism and seamlessness. ${ }^{(21)}$ Dogme, like the New Wave, deconstructs the traditional Hollywood iconography of establishing shots, three-point-lighting and continuity. They replace the seamless editing style 
with the jump-cut as an alternative to continuity editing, and on-location shooting as opposed to the Studio with occasional hand-held camera work. It is this informal approach to filmmaking, the sense of freedom and playful camera work, that the Dogme filmmaker borrows from the French New Wave and incorporates into their work to the extreme.

Despite Dogme's stylistic challenge, there are few narrational conventions that cannot be taken as entirely original of Dogme. Rather, Dogme shares from and with a small group of European Art Cinema authors such as Gaspar Noé, François Ozon, Claude Miller, and Philippe Grandrieux. They criticize and question social and political ideology and they touch upon sexual themes. In other words, they disrupt and confront the audience and the establishment. Dogme's tendency to confront and shock its audience has made its narratives earn the reputation of "R" rated films. As Richard Falcon puts it, Dogme's cinematic discourse "mimics a revolutionary stance that pretends to want to revive a modernist transgressive cinema within a sceptical post-modern climate". ${ }^{(22)}$ That is, Dogme reverses the modern approach where the shocking action remains confined to the off-screen space. The audience completes the meaning of the unseen event by inference. Consequently, the narrative at the affective level allows the sensation to be under the viewer's control. However, Dogme is structured around post-modern representation which alters the modern effect by trying to take over the viewer's mind by shocking them. The shocking effect is done by displaying the hidden object of the modernist, challenging the audience's moral and social codes. Although Vinterberg in The Celebration omits the display of "child abuse" scenery, he does not spare the audience of a forceful sexual scene after a stormy argument between the younger brother and his wife. In The Idiots, for example, one of the spas exercises culminates in a visual display of a group sexual orgy. There is no doubt that Dogme's post-modern transgressive narrative tone "gives to the commercially assimilable transgression of Hollywood a run for their money." (23)

Finally, what Dogme has been exploring with the "Vow of Chastity" and other narrational devices is the irony and paradox that is inherent in the technology and the production process itself. Even if the film was totally stripped of all production to a bare minimum, leaving it to just an improvised silent pantomime, even here everything would be artificially staged and not spontaneous. In the final analysis, there is no "candid camera." There is no "truth" since it is impossible for the camera lens to attain the very "substance" of things. The camera itself constitutes the very framework from which subjectivity emanates. Cinema by its very nature remains subjective. Therefore, the irony inherent in Dogme 95 as it tries to separate itself from the illusion of the mainstream cinema, is that it attempts to capture a completely "natural" scenario and drama (i.e., a factual event) by "artificially" (i.e., a fictional contrivance) viewing it through a man-made

lens. Yet, its very endeavour is in some measure successful since it does succeed in bringing home to the audience the idiocy, paradox, and futility of such an endeavour.

\section{Notes}

1. Schepelern, Peter. "Film According to Dogma: restrictions, obstractions and liberations". http://www.dogme95.dk/news/interview/schepelern.htm.

2. Durbin, Karen. "Making the Waves." New York Times Magazine. May 21 (2000).

3. Von Trier, Lars and Vinterberg, Thomas. "Dogme 95 Manifesto and Vow of Chastity" http://www.doame95.dk/menu/ment

4. Ibid.

5. Combs, Richard and Durgnat, Raymond. "Game" Film Comment 36:5 September - October (2000): 29.

6. Ibid., 31.

7. Bazin, Andre. What Is Cinema. (University of California Press, Berkeley and Los Angeles, 1967), 13.

8. Ibid. 9. Ibid. 10. Ibid., 15. 
11. Mattews, Peter. "Divining The Real" Sight \& Sound Vol. 9 issue 8 August (1999): 23.

12. Arnheim, Rudolf. Film As Art. (University of California Press. Berkeley, CA, 1957.

13. Ibid., 34.

14. Von Trier, Lars and Vinterberg, Thomas. "Dogme 95 Manifesto and Vow of Chastity" http://www.dogme95.dk/menu/mer

15. Bordwell, David. Narration in Film. (University of Wisconsin Press, Madison, Wisconsin. 1985), 206.

16. This is a clear example where the "existentialist" enters the scene in a postmodern re-examination and declares that reality is what one chooses it to be. Therefore, Any objectivity emerges from one's own subjectivity.

17. Schepelern, ibid.

18. Bordwell, David. "The Art Cinema as a Mode of Film Practice." Film Criticism 4, Fall (1979): 56-64.

19. Porton, Richard. "Something Rotten in the State of Denmark: An Interview with Thomas Vinterberg" Cineaste Vol. 24, issue 2-3 (1999): 17-19.

20. Cardullo, Bert. What is Neorealism? (University Press of America, NY, 1991), 87.

21. Mayne, Richard. "Still Waving Not Drowning" Sight 63 Sound Vol. 59, issue 3 (1990): 201-202.

22. Falcon, Richard. "The new European cinema wants to outrage us, but are we still shockable, asks Richard Falcon" Sight 83 Sound Vol. 9, issue 1, (1999): 10-13.

23. Ibid., 10.

\section{Author Information}

Gabriel GIRALT is Professor of Communication at the University of Akron (Ohio). He has presented academic papers nationally and internationally and has won several awards in Film and Video festivals. 